\title{
UPAYA PENINGKATAN AKTIVITAS BELAJAR MELALUI STRATEGI GROUP RESUME
}

\author{
Maryani \\ Guru Sekolah Dasar Negeri 04 Kecamatan Pontianak Timur
}

\begin{abstract}
Abstrak : Penelitian ini bertujuan : (1) Ingin mengetahui kemampuan siswa didalam melaksanakan pembelajaran akhlak dengan menggunakan strategi group resume; (2) Ingin mengetahui pelaksanaan tindakan siklus I untuk meningkatkan kemampuan pembelajaran akhlak melalui strategi group resume (3) Ingin mengetahui pelaksanaan tindakan siklus II untuk meningkatkan kemampuan pembelajaran akhlak melalui strategi group resume. Subjek penelitian ini adalah siswa kelas V SDN 04 Pontianak Timur yang berjumlah 34 orang. Teknik pengumpulan data digunakan dengan data catatan, data instrumen, data tentang situasi belajar mengajar dikelas, data penilaian siklus I dan data penilaian siklus II. Hasil penelitian menunjukkan bahwa siklus I perolehan pelaksanaan pembelajaran menjadi 67,91 (70\%) kategori baik. Siklus II perolehan pelaksanaan pembelajaran sebesar 80,41 (83\%) kategori baik sekali.
\end{abstract}

Kata Kunci : Pembelajaran Akhlak,Pendekatan Moral

\section{PENDAHULUAN}

Sebagai pengajar atau pendidik, guru merupakan salah satu faktor penentu dari keberhasilan pendidikan. Itulah sebabnya setiap adanya inovasi pendidikan, khususnya dalam kurikulum dan peningkatan sumberdaya manusia (SDM) yang dihasilkan dari upaya pendidikan selalu bermuara pada faktor guru. Hal ini menunjukkan bahwa betapa pentingnya peran guru dalam dunia pendidikan.

Besarnya peran guru dalam dunia pendidikan, seiring pesatnya perkembangan ilmu pengetahuan dan teknologi dewasa ini, perlu adanya penyesuaian-penyesuaian, terutama sekali yang berkaitan dengan faktorfaktor pengajaran di sekolah. Salah satu faktor tersebut, adalah strategi pembelajaran yang perlu dipelajari dan dikuasai guru, sehingga guru dapat menyampaikan materi pelajaran kepada siswa secara baik, berdaya guna dan berhasil guna.

Penelitian tindakan kelas juga dapat membantu guru meningkatkan profesionalismenya. Melalui penelitian tindakan kelas, guru bisa menyadari keterbatasan dirinya sehingga terus melakukan pengembangan atas potensi dirinya, kreativitas dan komitmen terhadap pengembangan profesinya. Beranjak dari pemikiran tersebut, selaku Guru Pendidikan Agama Islam di Sekolah Dasar Negeri 04 Kecamatan Pontianak Timur ingin melakukan penelitian tindakan kelas, khususnya dalam rangka meningkatkan aktivitas belajar siswa kelas V melalui strategi group resume.

Penggunaan strategi group resume bukanlah hal yang baru di dunia pendidikan, terutama bagi guru yang ingin meningkatkan aktivitas belajar siswa dan kualitas mengajarnya. Melalui strategi group resume kesempatan siswa untuk terlibat secara aktif dalam belajar semakin luas. Agar harapan tersebut tercapai, hendaknya perlu melakukan perencanaan program pengajaran dan melaksanakannya secara sungguhsungguh.

Pada pembelajaran Pendidikan Agama Islam, salah satu materi yang dianggap tepat dilaksanakan melalui penggunaan strategi group resume 
adalah materi akhlak, karena materi akhlak akan dapat dikuasai siswa secara baik manakala melalui penggunaan strategi dimaksud diyakini dapat mengaktifkan wawasan berpikir siswa, tentunya disertai pemberian bimbingan secara intensif kepada siswa di kelas.

Adapun masalah yang diangkat pada penelitian ini adalah; (1) Bagaimanakah aktivitas belajar siswa kelas V Sekolah Dasar Negeri 04 Kecamatan Pontianak Timur sebelum menggunakan strategi group resume?, (2) Bagaimana proses pembelajaran di kelas V Sekolah Dasar Negeri 04 Pontianak Timur dengan materi akhlak melalui strategi group resume? (3) Bagaimanakah aktivitas belajar siswa kelas V Sekolah Dasar Negeri 04 Kecamatan Pontianak Timur setelah menggunakan strategi group resume?

Apakah melalui strategi group resume dapat meningkatkan aktivitas belajar siswa kelas V Sekolah Dasar Negeri 04 Kecamatan Pontianak Timur?

Sesuai dengan permasalahan yang dikemukakan diatas maka penelitian ini bertujuan untuk:

Untuk mengungkapkan aktivitas proses pembelajaran di kelas $\mathrm{V}$ Sekolah Dasar Negeri 04 Kecamatan Pontianak Timur dengan materi akhlak melalui strategi group resume. Untuk mengkaji aktivitas belajar siswa kelas V Sekolah Dasar Negeri 04 Kecamatan Pontianak Timur setelah menggunakan strategi group resume.

Untuk mendeskripsikan ada tidaknya peningkatan aktivitas belajar siswa kelas V Sekolah Dasar Negeri 04 Kecamatan Pontianak Timur setelah menggunakan strategi group resume. Manfaat Teoritis: Hasil penelitian ini diharapkan bermanfaat sebagai upaya meningkatkan proses belajar, khususnya berkenaan dengan penggunaan strategi pembelajaran group resume.
Hasil penelitian ini diharapkan dapat bermanfaat sebagai bahan referensi di perpustakaan Sekolah Dasar Negeri 04 Kecamatan Pontianak Timur yang dapat dibaca oleh semua rekan guru dalam rangka menambah wawasan dan pengetahuan, khususnya berkaitan dengan penggunaan strategi group resume, dan upaya untuk meningkatkan aktivitas belajarnya.

Manfaat Praktis penulisan ini bagi peneliti, dapat mengaplikasikan disiplin ilmu yang telah diterima ketika mengikuti pendidikan dan pelatihan Penulisan Karya Ilmiah serta pengalaman menempuh perkuliahan dalam menemukan kebenaran secara ilmiah, terutama berkaitan dengan meningkatkan aktivitas belajar siswa melalui penggunaan strategi group resume.

Bagi sekolah, diharapkan dapat bermanfaat dalam mengetahui kinerja guru serta peningkatan kualitas proses dan hasil belajar Pendidikan Agama Islam. Bagi guru, diharapkan menjadi bahan kajian dan informasi untuk mengembangkan berbagai strategi dalam proses belajar mengajar.

\section{METODE}

Upaya memecahkan masalah dalam penelitian ini, maka diperlukan suatu metode yang tepat, sehingga kegiatan yang dilakukan lebih jelas, terarah serta mudah dipahami. Metode yang digunakan dalam penelitian tindakan kelas (PTK). Susilo (2009:16) menyatakan, bahwa PTK adalah suatu penelitian yang dilakukan oleh guru di kelas atau di sekolah tempat mengajar dengan melakukan penekanan pada penyempurnaan atau peningkatan praktik dan proses pembelajaran.

Direktorat Jenderal Pendidikan Dasar dan Menengah menggariskan, bahwa penelitian harus diawali dengan tahapan pra-PTK, meliputi: 
Identifikasi masalah, analisis masalah, rumusan masalah, dan rumusan hipotesis masalah (Wibawa, 2004:22). Pada tahapan dimaksud dan selanjutnya tahapan pelaksanaan PTK, sebagaimana berikut.

Suatu rencana Penelitian Tindakan Kelas (PTK) diawali dengan adanya masalah yang dirasakan atau disadari oleh guru. Kemudian secara langsung mengadakan observasi terhadap pembelajaran yang dilakukan, dan melihat aktivitas belajar siswa sebelum menggunakan strategi group resume.

Pada tahap pra PTK, data yang dihimpun dari hasil observasi yang dilakukan terhadap pembelajaran di kelas, selanjutnya melakukan identifikasi masalah. Permasalahan tersebut, meliputi (a) Siswa tidak memperhatikan penjelasan guru; (b) Siswa acuh tak acuh terhadap guru; (c) Sebagian besar siswa tidak mencerna mengenai materi yang diterangkan kepada siswa; (d) Jika disuruh bertanya hanya siswa tertentu yang melakukannya; (e) Berbicara dengan teman sebangku; (f) Bergurau dan mengganggu teman yang lain; dan (g) Disaat guru mengajukan pertanyaan, siswa enggan untuk menjawab.

Setelah melakukan identifikasi masalah, peneliti melakukan analisis terhadap masalah yang ditemukan, berkaitan dengan aktivitas belajar siswa yang ditinjau pengaruhnya terhadap pembelajaran. Kemudian masalah yang ditemukan tersebut dirumuskan secara menyeluruh, dimana pada tahap selanjutnya barulah dilakukan tindakan tahapan rumusan hipotesis.

\section{HASIL DAN PEMBAHASAN HASIL \\ Penelitian Tindakan Siklus I}

Pada awal pembelajaran, dan sebelum memulai salam pembuka sebagai improvisasi menanyakan kesiapan belajar kepada siswa, dan terdengar suara siswa secara bersamaan mengucapkan "siap bu". Ketika mengucapkan salam juga mendapatkan jawaban dan siswa secara bersamaan, untuk dilanjutkan membaca basmallah secara bersamasama. Kemudian menyampaikan tujuan pembelajaran yang hendak dicapai pada pembelajaran yang akan diselenggarakan tersebut, dilanjutkan dengan pemberian pre test kepada siswa tentang materi yang akan dipelajari tersebut.

Pada tahap pembelajaran inti, selaku Guru Pendidikan Agama Islam menyampaikan penjelasan materi akhlak, tentang Riwayat dari Khalifah $\mathrm{Abu}$ Bakar. Kemudian guru memberikan aturan dalam menjalani strategi group resume, bahwa pertama siswa diminta membentuk kelompok, sehingga di kelas $\mathrm{V}$ terbentuk atas 5 kelompok dalam rangka menjelaskan perilaku yang patut diteladani dari Khalifah Abu Bakar. Berkenaan hal tersebut meminta siswa untuk menanyakan hal-hal yang kurang dipahaminya berkenaan pembelajaran tersebut.

Setelah belajar mengajar berlangsung, selanjutnya meminta siswa untuk berani bertanya, untuk mempertanyakan hal-hal yang masih membuatnya bingung, ternyata masih ada siswa yang kebingungan dan mempertanyakannya kepada guru, pertanyaan siswa tersebut tidak sertamerta di jawab, tetapi dilemparkan dulu kepada kelompok siswa lainnya, dan selaku guru tinggal meluruskan apa yang di jawab siswa, serta melakukan penegasan atas kebenaran yang semestinya diketahui siswa.

Upaya melihat kemampuan dari aktivitas belajar siswa, dan keberhasilan pengajaran yang dilakukan, selanjutnya melakukan post test dengan mengajukan beberapa soal berbentuk essay dalam rangka 
memberikan feed back atas jawabanjawaban siswanya. 5 menit sebelum pembelajaran berakhir, selaku guru langsung memberikan motivasi akhir kepada siswa kelas V, supaya mereka tetap semangat dalam aktivitas belajarnya. Selanjutnya lagsung mengucapkan hamdalah yang diikuti seluruh siswa kelas V. dan guru pun mengakhiri pembelajaran.

Setelah dilakukan perhitungan atas hasil observasi siswa pada siklus I di kelas V Sekolah Dasar Negeri 04 Pontianak Timur mengenai materi akhlak pada Pembelajaran Pendidikan Agama Islam didapatkah nilai rata-rata aktivitas belajar siswa kelas V sebesar 67,91 dan dianggap masuk dalam kualifikasi penilaian baik, sehingga peneliti berkesimpulan perlu melakukan 'konfirmasi' penelitian, khususnya mengedepankan pengembangan dan penerapan strategi group resume pada siklus II dalam rangka meningkatkan hasil belajar siswa yang lebih baik memuaskan.

\section{Penelitian Tindakan Siklus II}

Pada awal pembelajaran, dan sebelum memulai salam pembuka sebagai improvisasi menanyakan kesiapan belajar kepada siswa, dan terdengar suara siswa secara bersamaan mengucapkan "siap bu. Ketika mengucapkan salam juga mendapatkan jawaban dan siswa secara bersamaan, untuk dilanjutkan membaca basmallah secara bersamasama. Kemudian menyampaikan tujuan pembelajaran yang hendak dicapai pada pembelajaran yang akan diselenggarakan tersebut, dilanjutkan dengan pemberian pre test kepada siswa tentang materi yang akan dipelajari tersebut.

Pada tahap pembelajaran inti, selaku Guru Pendidikan Agama Islam menyampaikan penjelasan materi akhlak, tentang Riwayat dari Khalifah Abu Bakar. Kemudian guru memberikan aturan dalam menjalani strategi group resume, bahwa pertama siswa diminta membentuk kelompok, sehingga di kelas $\mathrm{V}$ terbentuk atas 5 kelompok, dan setiap kelompok ditugaskan mendiskusikan tentang perilaku yang patut diteladani dari Khalifah Umar bin Khattab. Berkenaan hal tersebut meminta siswa untuk menanyakan hal-hal yang kurang dipahaminya berkenaan pembelajaran tersebut.

Setelah belajar mengajar berlangsung, selanjutnya meminta siswa untuk berani bertanya, untuk mempertanyakan hal-hal yang masih membuatnya bingung, ternyata dari pertanyaan siswa sudah tidak terlihat lagi tanda-tanda kebingungan, karena telah terbiasa menjalani aktivitas belajar dengan strategi strategi group resume. Pertanyaan siswa hanya terjadi pada keinginannya dalam mendalami materi dimaksud kepada guru, pertanyaan siswa tersebut seperti biasa tidak serta-merta di jawab, tetapi dilemparkan dulu kepada kelompok siswa lainnya, dan selaku guru tinggal meluruskan apa yang di jawab siswa, serta melakukan penegasan atas kebenaran yang semestinya diketahui siswa.

Upaya melihat kemampuan dari aktivitas belajar siswa, dan keberhasilan pengajaran yang dilakukan, selanjutnya melakukan post test dengan mengajukan beberapa soal berbentuk essay dalam rangka memberikan feed back atas jawabanjawaban siswanya. 5 menit sebelum pembelajaran berakhir, selaku guru langsung memberikan motivasi akhir kepada siswa kelas $\mathrm{V}$, supaya mereka tetap semangat dalam aktivitas belajarnya. Selanjutnya lagsung mengucapkan hamdalah yang diikuti seluruh siswa kelas $\mathrm{V}$ dan guru pun mengakhiri pembelajaran.

Meningkatnya aktivitas siswa dalam melaksanakan evaluasi dalam 
rangka menilai hasil belajar siswa dalam penguasaan materi akhlak, membuktikan bahwa nilai rata-rata kelas pada siklus I sebesar 67,91 dapat ditingkatkan menjadi 80,41 pada siklus II, dan jika dibandingkan dengan hasil belajar siswa sebelum menggunakan strategi group resume terjadi selisih interval sebesar 25,12 poin, karena pada Pra-PTK nilai ratarata kelas hanya mencapai 55,29 dan meningkat menjadi 67,91 setelah menggunakan strategi group resume di siklus I dan kemudian mengalami peningkatan lagi hingga 80,41 pada siklus II.

Mengenai kondisi belajar siswa di kelas V Sekolah Dasar Negeri 04 Kecamatan Pontianak Timur.

\section{KESIMPULN DAN SARAN Kesimpulan}

Bahwa aktivitas belajar siswa berkenaan pembelajaran Pendidikan Agama Islam khususnya materi akhlak di kelas V Sekolah Dasar Negeri 04 Kecamatan Pontianak Timur pada siklus I menunjukkan, bahwa siswa umumnya kurang tertantang dalam mengikuti proses pembelajaran. Kondisi tersebut dinilai baik manakala dibandingkan sebelumnya yakni pada Pra-PTK di lakukan. Diketahui hasil belajar siswa pada saat pra penelitian menunjukkan aktivitas rata-rata nilai aktivitas belajar kelas V sebesar 55,29 dengan daya serap siswa di bawah 60 persen. Hasil tersebut mengalami peningkatan setelah dilaksanakan penelitian pada siklus I dimana telah menerapkan strategi group resume, dan berhasil meningkatkan rata-rata nilai aktivitas belajar kelas $\mathrm{V}$ menjadi 67,91 dengan daya serap siswa di bawah 70 persen.

Bahwa aktivitas belajar siswa berkenaan pembelajaran Pendidikan Agama Islam khususnya materi akhlak di kelas V Sekolah Dasar Negeri 04 Kecamatan Pontianak Timur pada siklus II menunjukkan, bahwa siswa umumnya semakin tertantang dan aktif dalam mengikuti proses pembelajaran. Kondisi tersebut semakin membaik manakala dibandingkan aktivitas belajar pada pembelajaran pada siklus I di lakukan. Diketahui aktivitas hasil belajar siswa pada siklus I menunjukkan rata-rata nilai aktivitas belajar kelas $\mathrm{V}$ sebesar 67,91 dengan daya serap siswa di bawah 70 persen. Hasil tersebut mengalami peningkatan setelah dilaksanakan penelitian pada siklus II dimana juga menerapkan strategi group resume, dan berhasil meningkatkan aktivitas rata-rata nilai aktivitas belajar kelas V menjadi 80,41 dengan daya serap siswa sebesar 80 persen.

Bahwa peningkatan aktivitas belajar siswa pada pembelajaran Pendidikan Agama Islam khususnya materi akhlak melalui penerapan group resume di kelas V Sekolah Dasar Negeri 04 Kecamatan Pontianak Timur, ternyata dapat meningkatkan interval nilai aktivitas belajar siswa sekitar 25,12 poin dan hasil Pra-PTK sekitar 55,29 (masuk kategori kurang) menjadi kategori baik pada siklus I dengan rata-rata perolehan nilai aktivitas belajar kelas $\mathrm{V}$ menjadi 67,91 dan semakin mengalami peningkatan pada siklus II setelah guru melakukan pengayaan dan variasi dan penerapan strategi group resume sehingga perolehan rata-rata nilai aktivitas belajar kelas V menjadi 80,41 dan masuk kategori sangat baik.

Bahwa secara deskriptif mengenai aktivitas belajar siswa relatif rendah dan sebenarnya masih dapat diupayakan dengan melakukan pembelajaran melalui penerapan strategi group resume. Kurang aktifnya siswa pada siklus I dikarenakan siswa masih terlihat masih bingung dan canggung untuk berinteraksi dengan temannya, dan 
guru tidak memiliki cukup waktu untuk melaksanakan seluruh skenario tindakan. Baru pada siklus II kondisi kelas dan semangat belajar siswa menunjukkan perubahan yang lebih baik. Proses pembelajaran Pendidikan Agama Islam khususnya materi akhlak lebih santai, rileks, riang dalam menyelesaikan tugas-tugas yang diberikan untuk diselesaikan secara berkelompok.

\section{Saran}

Mengenai penelitian tentang: Upaya Meningkatkan Aktivitas Belajar Melalui Strategi Group Resume Pada Materi Akhlak Di Kelas V Sekolah Dasar Negeri 04 Kecamatan Pontianak Timur, selanjutnya ada beberapa saran sebagai sumbangan pemikiran penulis, sebagaimana berikut.

Pada proses belajar mengajar, guru diharapkan dapat menjadikan strategi group resume sebagai suatu alternatif dalam pembelajaran Pendidikan Agama Islam, terutama dalam rangka meningkatkan kemampuan, aktivitas siswa dalam belajar Pendidikan Agama Islam.

Kegiatan pembelajaran dengan menggunakan strategi group resume diketahui sangat bermanfaat bagi guru dan siswa, sehingga diharapkan dapat dilakukan secara berkesinambungan dalam pembelajaran Pendidikan Agama Islam maupun mata pelajaran lainnya.

Berkenaan penerapan strategi group resume guru harus benar-benar memahami langkah-langkahnya, dan dapat mengelola waktu seoptimal mungkin. Peran guru sebagai fasilitator menjadi sangat penting.

\section{DAFTAR RUJUKAN}

Arikunto, Suharsirni. 1992. Prosedur Penelitian Suatu Tindakan Praktis. Jakarta: Reunika Cipta.
Fathurrohman, Pupuh dan Sobry Sutikno. 2007. Strategi Belajar Mengajar, Melalui Penanaman Konsep Umum dan Konsep Islami. Bandung: Refika Aditama.

Hadi, Sutrisno. 1998. Metodologi Research 2. Yogyakarta: Andi Ofset.

Hanafiah, Nanang dan Cucu Suhana. 2009. Konsep Strategi Pembelajaran. Bandung: Refika Aditama.

Nawawi, Hadari. 1995. Metodologi Penelitian Bidang Sosial. Yogyakarta: Gadjah Mada University Press.

Poerwadarminta, W.J.S. 1976. Kamus Umum Bahasa Indonesia. Jakarta: PN. Balai Pustaka.

Rasyid, Harun. 2000. Metode Penelitian Kualitatif Bidang Ilmu Sosial dan Agama. Pontianak: STAIN.

Riduwan dan Sunarto, H. 2007. Pengantar Statistika, untuk Penelitian Pendidikan, Sosial, Ekonomi Komunikasi, dan Bisnis. Bandung: Alfabeta.

Sanafiah, Faisal. 1995. Penelitian Kualitatif Dasar-Dasar dan Aplikasi. Jakarta: Rajawali Press.

Silberman, Mel. 2002. Active Learning. Yogyakarta: Yayasan Pengembangan Ilmu-Ilmu Pendidikan Islam.

Suryosubroto, B. 1997. Proses Belajar Mengajar Di Sekolah. Jakarta: PT. Rineka Cipta.

Usman, Moh. Uzer. 2001. Menjadi Guru Profesional. Bandung: PT. Remaja Rosdakarya.

Wibawa, Basuki. 2004. Penelitian Tindakan Kelas. Jakarta: Raja Grafindo Persada. 